\title{
ANALYSIS ON THE TRANSLATION OF TECHNICAL TERMS IN DISASTER MANAGEMENT: A CASE STUDY IN NEWS TRANSLATION BY NOVICE TRANSLATORS
}

\author{
Nur Saptaningsih
}

Faculty of Cultural Science, University of Sebelas Maret. nursaptaningsih@staff.uns.ac.id

\begin{abstract}
Technical term is a word that has a specific meaning within a specific field of expertise. Translation of technical terms is challenging and becomes one of the most factors influencing the process of translation. This paper discusses about the pattern of translation of technical terms in disaster management, with the focus on translation techniques and translation quality. This study analyses the translation of technical terms made by novice/student translators. The data include words and phrases belonging to technical terms in disaster management. The translation techniques used by the translators to render the meaning of the technical terms in disaster management were categorized based on those proposed by Molina and Albir (2002). The translation quality was measured with the translation quality assessment proposed by Nababan, Nuraeni, and Sumardiono(2012). Patterns of translation were then drawn. The examination reveals that there are three patterns used by eight translators in conveying the meaning of technical terms in disaster management. This study also pinpoints possible causes underlying the usage of translation technique in search of equivalences.
\end{abstract}

Keywords: technical terms, disaster management, translation techniques, translation quality, patterns of translation

\section{ABSTRAK}

Istilah teknis adalah kata yang memiliki makna khusus dalam bidang tertentu. Penerjemahan istilah teknis merupakan hal yang menantang dan menjadi salah satu faktor yang mempengaruhi proses penerjemahan. Makalah ini membahas tentang pola penerjemahan istilah teknis dalam bidang penanganan bencana, dengan berfokus pada teknik penerjemahan dan kualitas hasil terjemahan. Studi ini menganalisis hasil terjemahan istilah teknis oleh penerjemah pemelajar (pemula). Data meliputi kata dan frasa yang termasuk dalam istilah teknis dalam bidang penanganan bencana. Teknik penerjemahan 
yang digunakan oleh penerjemah untuk mengalihkan makna istilah teknis dalam bidang penanganan bencana dikategorikan berdasarkan pengklasifikasian menurut Molina dan Albir (2002). Kualitas hasil terjemahan diukur dengan menggunakan penilaian kualitas terjemahan menurut Nababan, Nuraeni, dan Sumardiono (2012). Pola-pola dalam menerjemahkan kemudian dianalisis dan disimpulkan. Hasil analisis menunjukkan bahwa ada tiga pola penerjemahan yang digunakan oleh penerjemah dalam mengalihkan makna istilah teknis dalam bidang penanganan bencana. Studi ini juga menyimpulkan penyebabpenyebab yang kemungkinan besar berpengaruh pada penggunaan teknik penerjemahan dalam pencarian padanan.

Kata kunci: istilah teknis, penanganan bencana, teknik penerjemahan, kualitas penerjemahan, pola penerjemahan

\section{INTRODUCTION}

Translation activities today have developed rapidly, and the tendencies of these activities expand to specific fields of expertise, like mining, technology, medicine, pharmacy, sport, agriculture, disaster management, and others. The nature of transferring intention in the source text (ST) into the target text (TT) is to provide solution for target readers who are lack of ability in understanding information in the ST.

News, either printed or online, is one of texts requiring rendition, for this type of text is significant for nearly all people in the world. They read news to get an idea about the people and their culture, as well as the problems they face in their original countries. Information about important events taking place in a certain country attracts the attention of not only domestic readers but also foreign readers. The presence of translation activities is noteworthy for it helps disseminating news in the international arena (Troqe\&Marchan: 2017). Those who have trouble reading in a foreign language, however, don't have the freedom of finding out this information without the help of a translator.

In Indonesia, news spreading information about disaster occurring in the country frequently come to be trending, and the translation carried out within this topic becomes more interesting and challenging due to the presence of specific terms in disaster and disaster management. One aspect that has to be taken into account when dealing with text in special branch of knowledge is the presence of specific terms. Let's take a look at the fragment of a text in Indonesian and its English translation below.

ST: Prioritas penanganan darurat saat ini adalah koordinasi, evakuasi, pencarian dan penyelamatan korban, pelayanan kesehatan, penanganan pengungsi, perbaikan darurat sarana prasarana yang rusak.

TT : Current priorities are coordination, evacuation, search and rescue operation, health services, refugee camp, and emergency rebuilding of damaged infrastructure.

The terms "koordinasi","evakuasi", "pencarian dan penyelamatan korban", "pelayanan kesehatan", "penanganan pengungsi", and "perbaikan darurat sarana prasarana yang rusak" in the above example have their own specific denotations: "coordination", "evacuation", "search and rescue for victim", "health service", "refugee handling", "emergency repair of damaged infrastructure", respectively. Those terms belong to technical terms, i.e. terms which have certain meanings and used in specific field of study. This definition is in line with Mrklun's

Surakarta English and Literature Journal

Vol.1, No.1 AUGUST 2018 
words (2011) that technical term is a word which has particular meaning within a certain field of study and used when communicating information concerning technical subjects. A technical term has a specific meaning understood to people knowledgeable about the field and involves the theory of or application of practical science and technology (David, 2017).

The success of translation lies on the hands of its translator. A translator has to be fluent in both source language and target language, understanding the meaning contained in the source text (ST) and producing words equivalent in the target text (TT). A translator shall not make any addition and reduction of meaning in the TT.

Translating technical terms presents its own unique challenges. First, grasping the meaning of technical term takes time because the meaning is contextually determined by the field of study. When translating technical terms, a translator should understand the detailed concept of a term because it can have different meaning when used in different situation and user, in different field of study. For instance, the term 'operation' in the field of healthcare means 'surgery underwent to a patient', however, it can mean "mathematical process such as addition" in the field of Mathematics and "an action to handle the impacts of hazard and disaster" in the field of disaster management. Second, a term has to be rendered accurately into TT using appropriate lexical equivalence. This type of translation deals with the maximum saturation of the particular terminology that is characteristic of a given branch of knowledge. Third, solution has to be set up properly when a term does not have direct equivalence in TT.

Studies on translation of technical terms have been explored by researchers with the concentrations on challenges or difficulties (Costeleanu: 2009; Раджабова: 2017), techniques (Lozano \& Matamala: 2009; Widarwati: 2015; Yulianita: 2017), ideology (Mahmudah\&Anis: 2018), and qualities of translation in the fields of law (Moghadam\& Far: 2015), religion (Yulianita: 2017), medicine (Lozano \& Matamala: 2009; Widarwati: 2015), and hydropower generation (Marklun: 2011). Some research on the translation and interpreting in the field of disaster management have been made, centering on the (g)localization of the graphic user interface of the disaster management system and documentation(Musacchio \& Panizzon: 2017) and interpreting services for foreign search and rescue teams (Burut\& Kurultay: 2014). One topic that is still rarely examined is the study on the translation of technical terms inthe field of disaster management. Moreover, analysis on the translation of technical terms translated by novice translators is limited. The present study investigates the techniques used by the translators to translate technical terms in the field of disaster management and the impact of the translation techniques on the quality of translation, with the focus on the patterns of translation from Indonesian into English.

\section{METHODOLOGY}

The linguistic data in this research are technical terms, which take forms of words or phrases,used in disaster management found in the news about tsunami occurring in Sunda Strait published by Kompas.com. Data were taken from the data source, and were validated based on the set criteria. The translation data were the techniques used by the translators to render the technical terms in disaster management in the source text into the target texts, and the information about translation quality covering accuracy and acceptability, which were obtained from raters as informants. 
The data in the forms of technical terms in disaster management were gathered using content analysis, by reading the whole text and labeling the technical terms in the source text, and then finding the translation in the target texts. The data of translation quality, in term of accuracy, were obtained by comparing and contrasting data in the source text and in the target text. Meanwhile, data for acceptability were obtained by measuring the naturalness of the terms in the target text. The data about translation quality obtained from the researcher were compared with those obtained from two informants to ensure the validity of evaluation. The evaluation was carried out by referring to translation quality instruments proposed by Nababan, Nuraeni, and Sumardiono (2012).

The linguistic data were categorized as technical terms in disaster management. Translation data were analyzed by grouping them based on the patterns of translation, connecting the translation techniques and quality. The patterns identified were later explained. Finally, conclusion was drawn based on the objectives of the study.

\section{FINDINGS AND DISCUSSION}

Twenty-nine data of technical terms in the ST and 232 data of translation in the TT, taking form words and phrases were analyzed. The analysis of the translation of technical terms in disaster management starts from the translation techniques used by the translators to render the meaning of technical term into target text, the contribution of the techniques to translation quality, to the patterns of translation made by the translators.

When translating technical terms in disaster management, various models were applied by novice translators in order to find equivalences in the target language. The analysis on both linguistic and translation data results in three patterns of translation: (1) same technique - same quality, (2) different technique - same quality, and (3) different technique - different quality.

(1) Same technique - same quality

The first pattern covers the tendency that technical terms in disaster management are rendered using identical translation technique contributing to the same level of translation quality. The followings are some examples in which the tendency occurs.

\section{Example 1}

ST :Update Tsunami Banten dan Lampung, 281 meninggal, 1.016 luka-luka, dan 57 hilang

TT : Banten and Lampung Tsunami Update, 281 dead, 1,016 injured, and 57 missing. The term "tsunami" refers to "a type of disaster" and this was conveyed in the same way using established equivalence (EE) technique by all translators because the equivalence of this term is already established and well-accepted in the target language.

\section{Example 2}

ST :Prioritas penanganan darurat saat ini adalah koordinasi, evakuasi, pencarian dan penyelamatan korban, pelayanan kesehatan, penanganan pengungsi, perbaikan darurat sarana prasarana yang rusak.

TT :Current priorities are coordination, evacuation, search and rescue operation, health services, refugee camp, and emergency rebuilding of damaged infrastructure.

Alike with the translation of "tsunami" in Example 1, "evakuasi" which means "escape of people from an area that contains threat or hazard to lives or property" is conveyed using EE technique for this term into "evacuation" which shares the same meaning and usage. The uses of EE 
technique in those cases contribute to high level of translation quality in terms of accuracy and acceptability, for the terms in both languages share identical meaning and the equivalence in the TT are commonly used in and available in English dictionary, as well as in technical dictionary and documents in disaster management.

The possibility of choosing the identical equivalence with single technique conceivably due to the universality of the terms and the fact that terms, in fact, are originated from English and derived into Indonesian with naturalization of spelling. Thus, when the translation is carried from Indonesian into English, established equivalence is already available for the term. Moreover, confirming Widarwati (2017), established equivalence is more possibly applied when the technical term consists of one word.

(2) Different technique - same quality

The second pattern is indicated withthe uses varioustechniques - more than one techniques - for translating the terms, and the uses of several techniques are attributable to the same translation quality.The following two examples will clearly illustrate this trend.

\section{Example 3}

ST $\quad$ :"Korban dan kerusakan ini terdapat di 5 kabupaten terdampak yaitu Pandeglang, Serang, Lampung Selatan, Tanggamus dan Pesawaran, " kata Kepala Pusat Data Informasi dan Humas BNPB Sutopo Purwo Nugroho, Senin (24/12/2018).

TT1 :"The victims and damages were found in five affected regencies: Pandeglang, Serang, South Lampung, Tanggamus, and Pasawaran," said Sutopo Purwo Nugroho, Head of Information Data and Public Relation Center of BNPB on December 24.

TT2 : "The victims and physical damage of this Tsunami were found in 5 regencies. They are Pandeglang, Serang, South Lampung, Tanggamus, and Pesawaran”, said Sutopo Purwo Nugroho, Head of Data, Information, and Public Relation of BNPN on Monday $(24 / 12 / 2018)$.

TT3 : "The victims and the destruction were found in the 5 impacted regencies, which are Pandeglang, Serang, South Lampung, Tanggamus, and Pesawaran," said Sutopo Purwo Nugroho, the head of the Information Data Center \& Public Relations Department of National Bureau of Disaster Management (24/12/2018).

"Kerusakan" in the ST encompasses the meaning of "physical damages (caused by the tsunami suffered by the people living in five regencies)". This term is conveyed in different ways, with the incorporation of two different techniques - established equivalent (EE) and the combination of EE and explicitation (EXPL). "Damages" in TT1 and "destruction" in TT3 express equal message with "kerusakan". Despite of the fact that the former is more frequently used than the latter, both are proper equivalences for the term. In TT2, the term is rendered with the presence of "physical", accompanying "damages". The explicitation of "physical" is contextually suitable with the message embraced in the ST, that the damage is more related to the physical damages caused by the tsunami, instead of the other type of damages, for example, casualties. Thus, the uses of those three different forms of equivalences, indeed, produce high level of faithfulness and naturalness.

\section{Surakarta English and Literature Journal}


(3) Different techniques - different quality

The most frequently tendency in translating technical terms is different technique-different quality pattern. In this case, technical terms are translated using different techniques and theseresult in different translation quality. Let us take a look at Example 4 and Example 5 to depict clear picture of this condition.

\section{Example 4}

ST :Penanganan darurat terus dilakukan di daerah yang terdampak tsunami di Selat Sunda.

TT1 :Emergency response is continuously carried out in the affected areas of the tsunami in Sunda Strait.

TT2 : Emergency management continues in areas affected by Sunda Strait Tsunami.

TT3 : Emergency handling continues in areas damaged by the tsunami in Sunda Strait.

TT4 : Emergency management procedures are ongoing in the tsunami-impacted areas at the Sunda Strait.

TT5 : Emergency procedures continue in areas affected by the tsunami in the Sunda Strait.

TT6 : Emergency evacuation has been hold in areas that hit by tsunami in Sunda Strait.

TT7 : The emergency operation had been continuing in the areas which were affected by the tsunami in Sunda Strait.

Within the Indonesian text, "penanganan darurat" encloses "emergency response as an effort to mitigate the impact of an incident on the public and environment (disaster)". This message is presented in various ways in the English version. The first technique incorporated to render this term is EE, as exemplified with the presence of "emergency response", "emergency handling", and "emergency operation". Either "response", "handling", or "operation" is possibly and commonly used in the context of responding to disaster. The uses of this technique contributes to high level of accuracy and acceptability. However, in the translation presented in TT2, TT4, TT5, and TT6, the terms used in the English text express different meanings to that in the ST. "Emergency evacuation" denotes more specific meaning than "emergency response"; it is urgent immediate egress or escape of people away from an area that contains an imminent threat, an ongoing threat or a hazard to lives or property. On the contrary, while particularization (PART) is used in TT6, generalization (GEN) is applied in TT2. "Emergency management" embodies more general meaning than "emergency response". It is the organization and management of the resources and responsibilities for dealing with all humanitarian aspects of emergencies which include preparedness, response, mitigation, and recovery. In other words, emergency response is a part of activities in management.

The uses of both generalization and particularization technique contribute to low level of accuracy. There are various reasons underlying the uses of particularization and among others are political reason, taboo (offensiveness), impoliteness, insignificance of information, and lack of ability in finding proper equivalence (Widarwati: 2015). However, in the case of "emergency response", the particularization happens as the result of translator's incapability in finding proper equivalence in the target text. The result of study contradicts with Akhiroh's study (2013: 49) that generalization and particularization give a positive effect on the accuracy of translation.

Despite of the fact that both techniques produce less accurate translation, the acceptability level is still maintained in the TT. This is so, perhaps, for the terms in the TT are available and they are contextually acceptable when used in the context, though, in fact, the meanings are different from those in the TT.

\section{Surakarta English and Literature Journal}


Unlike in the case of TT2 and TT6, discursive creation (DC) is applied in TT4 and TT5. Both "emergency management procedures" and "emergency procedures" refer to "a plan of actions in a certain order or manner, in response to an emergency event", and this definition is obviously out of the context. In spite of the fact that this technique produces inaccurate translation, the naturalness of the terms in the TT is maintained.

\section{Example 5}

ST :Sutopo menambahkan, ribuan personel gabungan dari TNI, Polri, BNPB, Basarnas, Kementerian PU Pera, Kementerian Sosial, Kementerian Kesehatan, Kementerian ESDM, BPBD, SKPD, NGO, relawan dan masyarakat dan lainnya terus melakukan penanganan darurat.

TT1 :...BPBD, SKPD, Non-Government Organizations, volunteers and the communities helped to search and rescue the remaining victims. 5

TT2 : ....Disaster Mitigation Agency (BPBD), Regional Working Units (SKPD), NonGovernmental Organizations (NGO), volunteers and other communities, still participated in doing the emergency operation.

TT3 : ... Province and District Disaster Management, NGOs, SKPD, and volunteers were providing immediate assistance to those affected.

TT4 :...The Regional Disaster Mitigation Agency (BPBD), The Regional Working Units (SKPD), NGOs, volunteers and the other communities continuously did emergency response.

Another case confirming the utilization of the third pattern is presented in Example 6. The presence of acronym in the example is frequent, and one of which is " $B P B D$ ". BPBD stands for Badan Penanggulangan Bencana Daerah and this belongs to a non-departmental government institution handling disaster management in the level of either province or regency. This acronym parallels with "the Regional Disaster Management Agency". Nevertheless, within the English text, the term is conveyed into four different versions. In TT1, " $B P B D$ " is straightly taken into English without any change. This pure borrowing technique constitutes accurate translation for no alteration of form and meaning is made, but it puts effect on low level of acceptability because the idea about $B P B D$ is not presented clearly in the TT, making this term unfamiliar. Taking a look at TT2 and TT4, discursive creation and pure borrowing techniques are used to transform the acronym into English. Alike in TT1, pure borrowing technique in this case happens to the retaining of $B P P D$ in the English version. Meanwhile, "Disaster Mitigation Agency" in TT2 and "The Regional Disaster Mitigation Agency (BPBD)" in TT4seem more out of context, for the English version has its own meaning differing from that in the ST."Mitigation" denotes "the lessening of impacts of hazards and related disasters" and the message is dissimilar to "management". In addition, the idea of "regional" is lost in the TT2. With regard to the use of both techniques, the translation is less faithful and less acceptable in the TT.Discursive creation is also employed by translator, as displayed in TT3. "Province and District Disaster Management" does not correspond to $B P B D$ for the English version has new meaning, which is management of disaster in province and district. However, in the ST, the agency works in the level of either province or regency, instead of both.

\section{Surakarta English and Literature Journal}


The uses of different techniques in the latest pattern of translation have produced various levels of translation quality. Generalization, particularization, and discursive creation cause translation less faithful to the original text, while borrowing reduces naturalness of the translation. Dealing with the translation of acronym, the idea about agency or institution is not identified wholly by the translators and thus, this possibly causes them to create improper equivalence.

The details of explanation suggest that equivalence in the TT is the mainpointwhen producing translation of technical terms. In search of equivalence, the concept or ideas contained in the term has to be identified by the translator. Understanding the concept is the key which ensures that the correspondence produced is proper. Examination of parallel texts and related documents can be used at optimum level to help translator understand the concept and context of term in certain field. Study on parallel texts can help answers what dictionaries cannot. Deeper concern on the use of glossary is also suggested since glossary of terminologies many problems with the meaning of terminology: it is a tool to help decide whether a term is appropriate in each particular case. (David: 2017). Moreover, a high level of mastery in the source language is needed (Hosseinimanesh \& Dastjerdi, 2013). For sure, besides linguistic and cultural aspects, in the case of translation of technical terms, the competence in specific area is a point that needs to be taken into account by a translator, because accurate translation cannot be made without basic knowledge of particular field (Costeleanu: 2009; Akhiroh: 2015).

\section{CONSLUSION}

Thy study explains patterns of using techniques and the impacts on quality of translation of technical terms in disaster management. This paper concludes that there are three patterns of translation made by translators - same technique-same quality, different technique-same quality, and different technique-different quality. Various techniques and quality of translation are made, implying the fact that translators, particularly novice translators, shall pay more attention on the grasping of idea attached in the term in the ST and finding proper equivalence in the TT, while giving more attention on the use of parallel and relevant texts in doing so. This research pinpoints the ways technical terms in disaster management translated from Indonesian into English. The similar tendency may occur for other pairs of languages. Thus, further study is required to confirm the question.

\section{REFERENCES}

Akhiroh, N.S. (2015). The influence of translation technique on the quality of the translation of international news in Seputar Indonesia Daily. Retrieved from http://citeseerx.ist.psu.edu/viewdoc/download?doi=10.1.1.865.8168\&rep=rep1\&type=pdf

Bulut, A. \& Kurultay, T. (2014). Interpreters-in-aid at disasters community interpreting in the process of disaster management. Retrieved from https://doi.org/10.1080/13556509.2001.10799104

Costeleanu, M. (2009).Difficulties in translating specialized texts.Retrieved from http://www.diacronia.ro/ro/indexing/details/A3362/pdf

\section{Surakarta English and Literature Journal}


Vol.1, No.1 AUGUST 2018

David. (2017). Translation of technical terms. Retrieved from https://www.contructivetranslation.com

Disaster Terminology, Retrieved from https://nidm.gov.in/PDF/Disaster terminology.pdf

Hosseinimanesh, L. \& Dastjerdi, H.V. (2013). Technical translation: A study of interference in three Persian Translations of "Software Engineering".Journal of Language Teaching and Research, 4, 1 (156-163)

Kompas.com. Update Tsunami Bantendan Lampung: 281 meninggal, 1016 luka-lukadan 57 hilang. 2018.2 Retrieved fromhttps://lifestyle.kompas.com/read/2018/12/24/09235691/update-tsunami-banten-danlampung-281-meninggal-1016-luka-luka-dan-57-hilang

Lozano, D. \& Matamala, A. (2009). The translation of medical terminology in TV fiction series: the Spanish dubbing of E.R. Retrieved from http://vialjournal.webs.uvigo.es/pdf/Vial2009-Article4.pdf

Mahmudah, Q. \&Anis, M. Y. (2018).Ideologipenerjemahan Arab - Indonesia dalamistilahistilahkeagamaan: Studikasuspenerjemahanteks Qurrat al-Ain. Proceeding ofMenilikUlangTeoridanPraktikPenerjemahan.

Marklun, A. (2011). Translation of technical terms: a study of translation strategies when translating terminology in the field of hydropower generation. Linnaeus University. Retrieved from http://www.diva-portal.org/smash/get/diva2:431449/FULLTEXT07

Musaccho, M.T. \& Panizzon, R. (2017). Localising or globalising? Multilingualism and lingua franca in the management of emergencies from natural disasters. University of Padova. Retrieved from http://www.cultusjournal.com/files/Archives/Musacchio_Panizzon.pdf

Molina, L \&Albir, A.H. (2002). Translation technique revisited: A dynamic and functionalist approach". Meta, XLVII, 4, (499-512).

Moghadam, M.Y. \& Far, M.D. (2015). Translation of technical terms: A case of law terms. Journal of Language Teaching and Research, 6, 4, (830-835). Retrieved from https://pdfs.semanticscholar.org/0fe9/b93a1c038a8ec46b55b8d3796f53e22b6f08.pdf

Nababan, M.R., Nuraeni, A., \&Sumardiono.(2012). Pengembangan model penilaiankualitasterjemahan KajianLinguistikdanSastra, 24, 1, (39-57).

Раджабова, А. (2017).Difficulties of the translation of scientific and technical texts.Retrieved from https://moluch.ru/archive/147/41270.

Troqe, R. \&Marchan, F. News translation: Text analysis, fieldwork, survey. In Silvia HansenSchirra, Oliver Czulo\&Sascha Hofmann (eds.), Empirical modelling of translation and interpreting, 277-310. Berlin: Language Science Press.

UNISDR terminology on disaster risk reduction.International Strategy for Disaster Management. Retrieved from https://www.unisdr.org/files/7817 UNISDRTerminologyEnglish.pdf

Undang-UndangRepublik Indonesia Nomor 24 Tahun 2007 TentangPenanggulanganBencana.

Widarwati, N. T. (2015). Taksonomidanteknikpenerjemahanistilahkedokteran.Proceeding of PESAT (Psikologi, Ekonomi, Sastra, Arsitektur\&TeknikSipil). UniversitasGunadarma. Depok.

Yulianita, N.G. (2017). Penerjemahanistilahreligi: Penilaiankualitaskeakuratan. Adabiyyāt: JurnalBahasadanSastra, I, 2(156-181).Retrieved from http://ejournal.uinsuka.ac.id/adab/Adabiyyat/article/download/01202/803

Surakarta English and Literature Journal 


\section{LIST OF ABREVIATIONS}

ST : source text

TT : target text

EE : established equivalent

EXPL : explicitation

DC : discursive creation

PART : particularization

GEN : generalization 